\title{
Un Respiro de Poesía en el Aula
}

\author{
Rubiela Márquez García ${ }^{10}$
}

\footnotetext{
${ }^{1}$ Institución Educativa Técnica Industrial Gustavo Jiménez rubymarga14@hotmail.es

Como citar: Márquez García, R. (2021). Un Respiro de Poesía en el Aula. EDUCACIÓN $Y$ CIENCIA, (25), e12546. https://doi. org/10.19053/0120-7105.eyc.2021.25. e12546
}

\section{Resumen}

El artículo muestra resultados de una investigación enfocada en dinamizar, describir y analizar experiencias estéticas e interpretativas desde la perspectiva teórica agujero o grieta del respiro, resignificada por Antonio Domínguez Rey, a lo cual se suman perspectivas de otros autores. Se recurrió al enfoque etnográfico educativo de corte cualitativo. Los sujetos de indagación fueron 32 estudiantes de grado sexto de un plantel educativo colombiano y la información se recolectó mediante encuesta, liturgias y tertulias literarias. Los resultados mostraron que la mayoría de los nińos tiene contacto con textos poéticos. Las liturgias fueron momentos de goce estético. Los niños tuvieron la posibilidad de conocer poetas vivos, escuchar su voz, dialogar con ellos, leer en voz alta algunas de sus creaciones y sumergirse en el mundo de la poesía. Con las tertulias literarias, los participantes se enfrentaron a textos poéticos diversos y mediante la inmersión en ellos, colmaron de sentido los agujeros, grietas, o vacíos luminosos, así, pudieron vivenciar estados de ensońación, a través de la imaginación y la añoranza, el asombro y la emotividad.

Palabras clave: poesía, ensońación, interpretación, agujero, imaginación.

Recibido: 03/03/2021 | Revisado: $15 / 03 / 2021$

Aprobado: 22/04/2021 | Publicado: 16/06/2021 


\title{
A Breath of Poetry in the Classroom
}

\begin{abstract}
The paper shows the results of research focused on dynamizing, describing, and analyzing aesthetic and interpretive experiences from the theoretical perspective hole or gap of respite, resignified by Antonio Domínguez Rey, and other authors. An educational ethnographic approach through a qualitative methodology was used. Participated 32 sixth grade students from a Colombian educational establishment and the information was collected through a survey, literary liturgy, and literary gatherings. The results showed that most children have contact with poetic texts. Liturgies were moments of aesthetic enjoyment. The children had the opportunity to meet living poets, listen to their voices, dialogue with them, read aloud some of their creations, and immerse themselves in the world of poetry. With the literary gatherings, the participants faced diverse poetic texts and by immersing themselves in them, filled with meaning the holes, gaps, or luminous voids, thus, they could experience dreamy states, through imagination and longing, amazement, and emotion.
\end{abstract}

Keywords: poetry, reverie, interpretation, hole, imagination.

\section{Introducción}

La facultad poética es connatural al lenguaje, por ello, conviene incluir la poesía en las aulas escolares, visibilizarla y darle un lugar preponderante para que los estudiantes la disfruten e interpreten. Bajo esta premisa, se desarrolló una investigación etnográfica educativa de corte cualitativo, cuyos objetivos consistieron en: 1) dinamizar la capacidad interpretativa de textos poéticos en estudiantes de grado sexto de una Institución colombiana $\left[\right.$ INEGS $^{1}$; 2) describir y analizar las experiencias estéticas desde la perspectiva teórica agujero o grieta del respiro planteada por Domínguez (2008) y, desde diversas miradas sobre la interpretación poética de autores como Bachelard (1998, 2002), Paz (2003), Avendaño (2020, 2018, 2010, 2006, 2005) y Goyes (2012). El estudio usó como instrumentos para recolección de la información una encuesta para conocer el contacto de los niños con la poesía, y, liturgias y tertulias literarias para generar experiencias estéticas mediante el goce e interpretación de poemas.

La investigación se justificó en la necesidad de ofrecer espacios para provocar en los estudiantes, experiencias de goce, ensueńo, imaginación, sensibilidad, asombro y emotividad. El interés se centró en detectar cómo los niños exteriorizan su experiencia estética al contacto con la poesía y los efectos que esto le producen, lo cual redunda en el mejoramiento de su interpretación lectora. El trabajo se fundamentó en el

1 Para resguardar la identidad de los sujetos involucrados en la investigación, se recurre a esta sigla. 
trasfondo poético del lenguaje, el ensueño de imaginación poética, la hermenéutica, volteo de palabras, agujero o grieta del respiro, la experiencia estética como opción liberadora del ser: aisthesis, catarsis y poiesis, y la pedagogía de la imaginación poética.

\section{Trasfondo Poético del Lenguaje}

El ser humano tiene la capacidad de poetizar porque en el lenguaje subyace el rasgo poético. Esa facultad poética está relacionada con las facetas sensibles, imaginativas, ingeniosas, emotivas y sensitivas, que le permiten a la persona crear e interpretar distintas manifestaciones del lenguaje — verbal, icónico, visual o sonoro- . Entonces, la poesía aflora del fondo poético innato de la lengua. Hoy la belleza de la poesía no se asimila al uso de vocablos artificiosos, rimbombantes, rebuscados, demasiado adjetivados y floridos, pues también son poéticas las palabras prosaicas, sencillas, mundanas, informales y de tono doméstico — sin prestigio poético—, que constituyen el desenfado expresivo, espontáneo, y el verbo descarnado (Avendaño, 2010).

El lenguaje del poema permite romper las convenciones, liberar la palabra y el pensamiento, porque surge del poder creador de la palabra donde el lector vivencia un goce que logra satisfacerlo. La poesía transforma el mundo, devela los sentimientos más profundos de lo humano. Paz (2003) la concibe como "conocimiento, salvación, poder, abandono" (p.13). Al tener contacto con ella se vive una experiencia indescriptible para algunos, porque genera emociones, sentimientos y evaluaciones de su diario vivir. Para Paz (2003), la poesía no es una representación de la realidad, es la realidad misma. La obra poética presenta la realidad, es una imagen de ella. Avendaño (2010) añade que al darle sentido a la poesía, se penetra en una representación hablada, allí se infiere y se aclaran muchas ideas; el poema se convierte en un espejo del hombre, de su ser, y de su relación con el mundo. Por su parte, Vásquez (2002) indica que gracias a la poesía se adquieren otros lentes para poder apreciar lo imperceptible a primera vista.

El papel de la poesía es relevante por su relación estrecha que guarda con el poema, Paz (2003) advierte que "El poema no es una forma literaria sino el lugar de encuentro entre la poesía y el hombre. Poema es un organismo verbal que contiene, suscita o emite poesía” (p.14). Es decir, el poema es el ánfora donde el poeta vierte toda su esencia humana, es la cristalización o condensación del momento en que fluyen las palabras mediante imágenes poéticas portadoras de múltiples sentidos (Avendańo, 2006). Dentro de los elementos constitutivos del poema destacan: la polifonía, que hace referencia a la diversidad de sonidos; la rima como una de sus formas más comunes en antaño, la cual, le imprimía sonoridad y musicalidad; y la redundancia o repetición, que está relacionada con las construcciones sintácticas que se reiteran y los paralelismos que surgen. Vale aquí mencionar las siguientes trasposiciones: la personificación, recurso ligado a la capacidad del poeta para darle 
vida a los objetos, es decir, para animar el mundo inanimado; la comparación, que permite asociaciones y correspondencias con otros objetos semejantes; y la metáfora, reina de las substituciones, transposiciones y símbolos (Perriconi \& Wischñevsky, 1984).

\section{Ensueño de Imaginación Poética}

La ensońación es la experiencia que muestra otra forma de ver la realidad. Bachelard (1998) señala que el acto de la ensońación poética despierta todos los sentidos, inspira, trasmite emoción, gusto y revive momentos. La ensońación busca el goce que proporciona lo bello, le da ilusión al sońador provocándole consolidar el mundo imaginario y crear sus anhelos y quimeras, lo conecta con el mundo. El instante de ensońación se convierte en un estado de felicidad, el poeta sale de sí y se transporta a otros mundos, y ello le produce sensaciones de libertad. La ensońación es el principio esencial de todo acto de creación y, por supuesto, del proceso de recepción del texto poético, porque quien lee el poema también se sumerge en un estado de ensońación. Domínguez (2008) indica que el lector de poesía cuenta con una facultad creativa de lectura, esto es, el aporte poético del lector, por su parte Pound (2000) notó que "el lector es también poeta; todos de alguna manera, hemos sido grandes poetas al leer los grandes poetas" (p. 37).

Avendaño (2018) entiende la ensońación poética como imaginación, esto es, fantasía, quimera, ilusión, ficcionalización, irrealidad o tiempo futuro, pero la ensoñación aloja, además, la remembranza, la evocación del tiempo pasado y también las vivencias presentes, es decir, conjuga lo irreal y lo real, la imaginación y la memoria. El poeta asocia en su proceso creativo imágenes reales — vivencias del pasado y del presentecon irreales - deseos o sueńos-. La ensońación poética que propone Bachelard, fue relevante como referente teórico en el desarrollo de este trabajo, por cuanto busca en el imaginario infantil el goce de la poesía y la creación de universos nuevos, a través del estudio de imágenes, la libertad de imaginación y de recuerdos, en sí, acciones ensoñadoras en el marco de la lectura, el disfrute y la hermenéutica de los poemas.

\section{Hermenéutica}

La hermenéutica como proceso interpretativo genera un encuentro con los saberes previos, con la experiencia y el contexto, para crear nuevas perspectivas del mundo. Cuando el lector interactúa con el texto poético desarrolla una función interpretativa en búsqueda de lo que está presente y lo que está oculto. Para Gadamer (1977), a través de la hermenéutica es posible comprender a un autor mejor de lo que él mismo se habría comprendido.

Según Avendaño (2005), para Todorov la interpretación no es un acto automático, se debe a que algo en el texto o fuera de él indique que el significado inmediato y explícito es insuficiente, que debe ser considerado tan solo como el punto de partida 
de un interrogante que desembocará en un segundo sentido, pues una característica del sentido es permanecer oculto en los planos de organización del lenguaje y del discurso mismo. Se podría decir que, especialmente, un texto poético dispara una multiplicidad de sentidos. Concomitante con lo anterior, Ricoeur (1999) concibe la interpretación como la búsqueda de un sensus plenior en todo sensus implicado, y ello a base de una distinción entre lo que se explicita y lo que se da a entender. Así, la interpretación es el proceso de pensamiento que consiste en descifrar el sentido traslapado en el sentido aparente, es decir, en la significación literal. Al leer surge un diálogo propio que consiste en preguntas sucesivas cuyas respuestas interrogan de nuevo (Avendaño, 2010).

Ahora bien, el Volteo de Palabra es un concepto de corte hermenéutico que proviene de los postulados de San Agustín y consiste en el acto de transformar, poner al revés para hender, escudriñar, hacer analogías, analizar, interrogar e interpretar el texto. El volteo de palabras se da para dotar de más significado y extender las palabras hacia un a priori metonímico, así el lector asume un rol activo: entra en el texto, bucea en él, interactúa, siente, entiende, cuestiona y valora, para luego salir renovado (Avendaño, 2010). Pero este fenómeno hermenéutico no solo se da en la recepción del texto poético, pues ya ha ocurrido en el de su creación; autor y lector centran su atención en las palabras, las sacan a la luz, juegan con ellas, crean otras y las dotan de sentidos impensados. Al respecto, Paz (2003) refiere que la lectura del texto poético implica una tarea similar a la de su creador, es decir, se trata de darle la vuelta a las palabras, darle familia a los vocablos huérfanos, dar nombre a lo que se desvanecía en la oscuridad -agujero-, cantar, gritar y revelar los silencios de los sueńos.

El Agujero o Grieta del Respiro es una lectura entre líneas. Para Domínguez (2008) el lector entiende más de lo que aparece explicitado. La lectura nunca se agota, es infinita. La palabra entendida aún contiene más mundo oído y por decir, lleva otra palabra a cuestas no prevista por el código, pero que lo rehace, se calla si no se le interroga y vive del silencio. La expresión realmente es una grieta o agujero, en donde respira lo innominado y singular de todo nombre, se arquea y solidifica para encubrir el rumor inabarcable de la realidad. La forma escritural trasciende en un exotismo que la invierte más allá de su representación, abre la puerta de la imaginación creadora del lector, quien pone la obra en escena y la hace hablar, pues el poema está recubierto de opacidades.

El desentrañe de sentidos que reposan en los agujeros se logra por la interacción activa entre el mundo del lector, del poema, del autor y de los contextos. Esos agujeros del texto realmente son vacíos luminosos que expelen multiplicidad de sentidos y es el lector quien los rescata, los atrapa en su proceso interpretativo. La imaginación es un estado perfecto para llenar esos agujeros; gracias a ella se crean nuevos sentidos y formas de ver lo que subyace en la obra (Avendaño, 2010).

A partir de los anteriores supuestos, se acercó a los estudiantes a la poesía para que la disfrutaran, interpretaran y se sumergieran en estados de ensońación, pues "la 
comprensión de un texto requiere que el entendimiento de las ideas en él reflejadas se haga propio en uno mismo" (Domínguez, 2008, p. 289).

\section{La Experiencia Estética como Opción de Liberación del Ser: Aisthesis, Catarsis y Poiesis}

Las experiencias estéticas se dan en tres planos: Poiesis, conciencia productiva que hace referencia al proceso de creación artística, a la capacidad poética. Aisthesis, percepción estética, y Catharsis, posibilidad liberadora, conciencia subjetiva. Jauss (1986) concibe la catharsis como "el goce que genera en las propias emociones, entre otras creaciones, la poesía, y que puede hacer cambiar de criterio y liberar el ánimo del lector" (p.159). El niño en su proceso interpretativo del poema libera tensiones cotidianas, vierte sus emociones, sentimientos y presaberes, cambia o reafirma convicciones. Se accede a una experiencia de catharsis gracias al goce estético, pues cuando el sujeto está inmerso en el poema, experimenta estados de ensueño, asombro, compasión y emoción. Además, la catharsis involucra el proceso comunicativo que le permite al lector reflexionar sobre lo poético.

\section{Pedagogía de la Imaginación Poética}

La pedagogía de la imaginación poética exige participación activa y creativa de todos los estamentos educativos; debe basarse en lo que se sabe, se siente y se imagina, pasando por el umbral de la interpretación hasta lograr estadios de transformación holísticos en el saber, el sentir y el imaginar cómo práctica pedagógica social. Así mismo, es una vía de transformación cultural e histórica y puede desencadenar una nueva educación para la convivencia. Esta pedagogía le permite a los estudiantes recurrir a la historia y a sus propias experiencias de vida, para crear símbolos latentes en su realidad, además, la poesía activa valores lingüísticos que brindan herramientas para disfrutar y fortalecer la capacidad interpretativa. Por ello, vincular este tipo de pedagogías resulta relevante, pues aunque la escuela la estimula el pensamiento lógico y racional, generalmente olvida la faceta emocional de los estudiantes (Goyes, 2012).

Se considera significativo abordar la experiencia interpretativa en el aula así: leer en voz alta y silenciosamente el poema o escucharlo en un audio, si es posible; formular preguntas a los estudiantes como ¿Qué sensaciones e impresiones les suscitó? ¿Qué les evocó? ¿Qué imaginaron? ¿Qué sentimientos les despertó, alegría, nostalgia, asombro, desconsuelo, decepción, ira, repudio? ¿Cuál es el motivo temático? ¿Cuáles son las imágenes poéticas que contribuyen a la construcción del sentido? ¿Qué otros temas gravitan alrededor de la temática central? ¿Qué asociaciones con su propio entorno les provocó?

\section{Metodología}

El horizonte metodológico de la investigación se enmarcó en el paradigma 
hermenéutico, puesto que es necesario comprender e interpretar el objeto de estudio, el entorno y el grupo social. De acuerdo con Pievi y Bravin (2009), no se trata de hallar la regularidad de hechos externos que se imponen a los sujetos, sino de entender el sentido de las prácticas sociales que estos desarrollan en función de la significación que endilgan al mundo. Este trabajo pretendió dinamizar experiencias interpretativas de estudiantes de grado sexto de la institución INEGS, a partir del contacto con la poesía, para luego, describir y analizar tales experiencias a la luz de la teoría del agujero o grieta del respiro (Domínguez, 2008), y de las posturas de Bachelard (1998, 2002), Paz (2003), Avendaño (2020, 2018, 2010, 2006, 2005) y Goyes (2012), a fin de aportar conocimiento teórico y pedagógico a los estudios literarios.

Para el desarrollo de la investigación se adoptó el enfoque cualitativo porque al generar experiencias estéticas del texto poético en el aula, se busca conocer, describir, comprender, analizar e interpretar el fenómeno objeto de estudio. El estudio se apoyó en la perspectiva etnográfico-educativa, que permitió la observación e inmersión con la población objeto de esta indagación. Se recurrió a la encuesta, la liturgia y la tertulia literaria, como instrumentos de investigación. La liturgia es entendida por Palomo (2013) como una estrategia didáctica para acercar la literatura a los estudiantes, tiene un propósito sensibilizador durante los primeros 20 minutos de la jornada. La tertulia se entiende aquí como espacio de conversación para disfrutar e interpretar poemas. El procedimiento que orientó el trabajo de campo fue: 1) Exploración diagnóstica, diseño y aplicación de una encuesta con cinco preguntas de selección múltiple para conocer la relación de los niños con la poesía; 2) diseño de liturgias y tertulias literarias, apoyadas en un corpus de poemas infantiles y un guion de preguntas; 3) encuentros con la poesía en el aula; 4) descripción y análisis de las experiencias estéticas e interpretativas de los estudiantes.

\section{Resultados y Discusión}

Para la sistematización de la información se determinaron como categorías de análisis: contacto con la poesía; lectura de poemas en el aula; tipos de textos poéticos que se leen en el aula; y poemas que desearían leer según motivos temáticos. A continuación, se muestran los resultados, el análisis y la interpretación respectiva.

Inicialmente, se evidencia que el 93\% de los participantes manifestó estar familiarizado con la poesía, el 7\% restante, respondió de manera negativa a la relación con el género literario. Así mismo, el 59\% de los estudiantes seńalaron que aprenden los poemas de memoria, el $7 \%$ analiza la estructura de cada poema y lectura en casa con sus padres; el $4 \%$ imagina los poemas, los dibuja, los disfruta, los pone en práctica, saca conclusiones y hace actividades para mejorar expresión oral (figura 1). Los datos revelan que en el aula se recurre con mayor frecuencia a la declamación y al estudio estilístico de los poemas. 
Sobre el tipo de textos poéticos que se abordan en el aula, se evidencia que existe una prelación por los poemas (78\%) y las coplas (70\%). Las canciones, acrósticos, rondas y caligramas se presentan en proporción descendente (figura 2). Se infiere que los estudiantes identifican maneras diversas de expresar la capacidad de poetizar y comprenden que no solo los poemas hacen parte de la poesía, sino que existe una gama amplia de posibilidades para plasmar el pensamiento creativo literario.

\section{Figura 1}

Lectura de Poemas en el Aula.

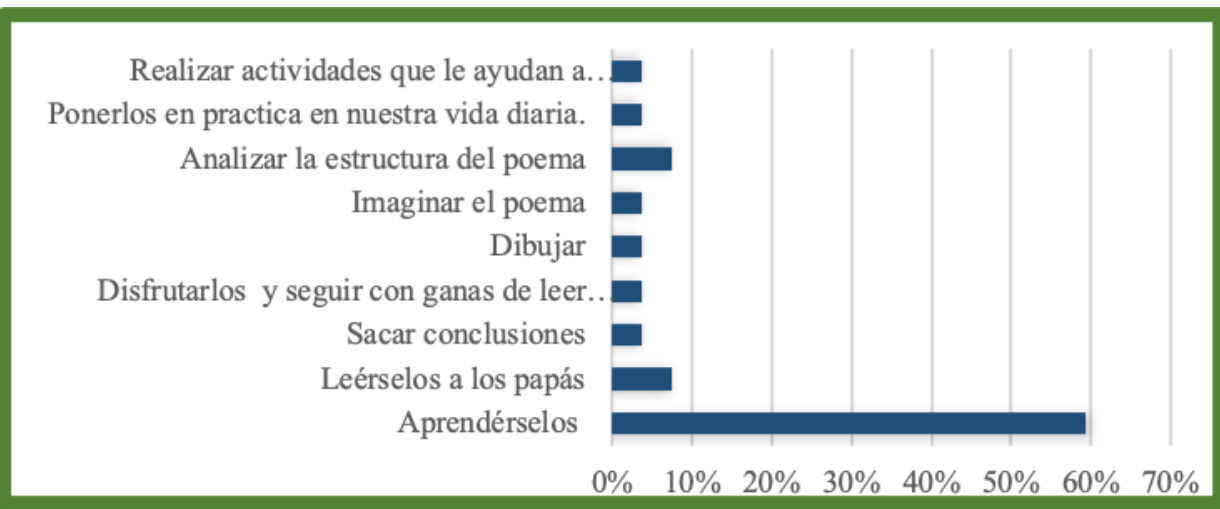

Respecto a la temática de los poemas, los animales y familia, la lluvia, el mar y la nieve son los de mayor interés para los estudiantes. También manifestaron gusto por los viajes, aventuras, colores, flores, el amanecer y duendes, los juguetes y plantas, barcos y la noche, los astros y días de la semana (figura 3). Se concluye que las temáticas sobre animales y familia son de mayor agrado, porque atañen a su entorno.

Figura 2

Tipos de Textos Poéticos que se Leen en el Aula.

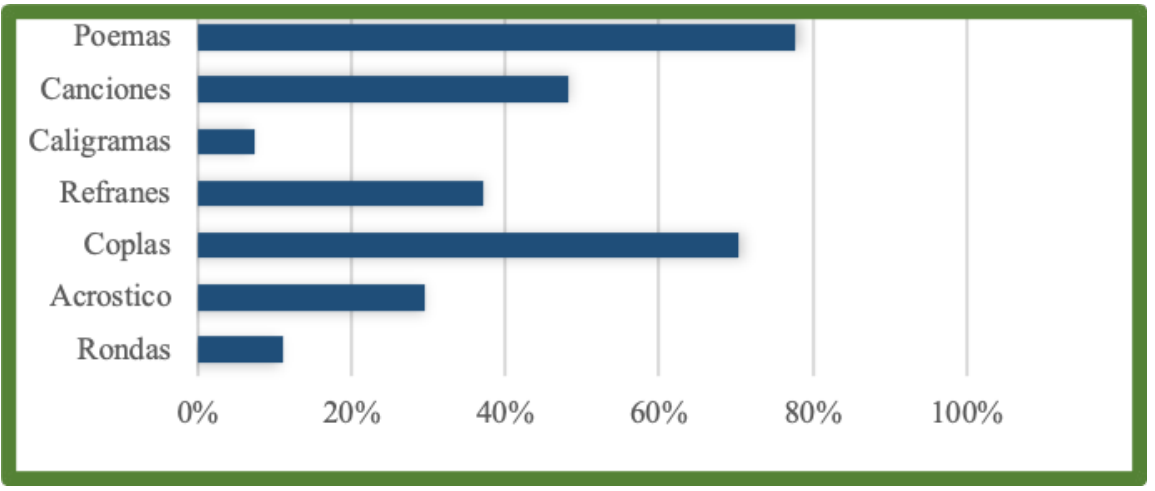

Se destaca que este ejercicio diagnóstico resultó de gran relevancia, pues conocer los intereses de los nińos permitió seleccionar adecuadamente el corpus objeto de las liturgias y tertulias. Esta fase exploratoria evidenció que los estudiantes leen poesía en el aula y con los papás, actividad que disfrutan. La mayoría prefiere poemas con 
temáticas cercanas como los animales y la familia. También, en el aula se implementan estrategias apoyadas, principalmente, en la memorización y en el análisis estilístico de los poemas, pero se descuida la búsqueda y la construcción del sentido. Con estos hallazgos se diseñaron cinco liturgias y siete tertulias ancladas en un corpus de poemas infantiles. A continuación, se describe y se analiza la primera liturgia y tertulia.

Figura 3

Poemas Que Desearian Leer Según Motivos Temáticos.

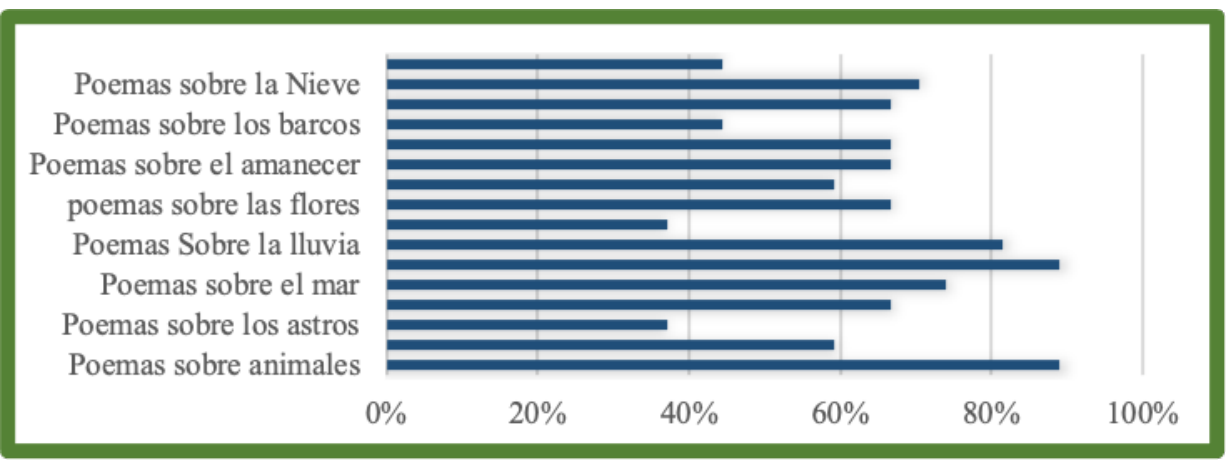

Experiencias Estéticas e Interpretativas en el Seno de las Liturgias Literarias

Las liturgias literarias se enfocaron en escuchar la lectura de poemas de la propia voz del autor, para introducir a los niños en la creación estética, sensibilizarlos y despertar emotividades. Se estructuró en dos momentos: 1) contacto con una voz poética viva, que incluyó la presentación del poeta invitado y comentario breve sobre su experiencia poética; 2) sensibilización, ensońación y disfrute poético a través de la lectura en voz alta de poemas del autor presentado, y socialización de emociones suscitadas, a través de plataformas virtuales, debido a las circunstancias de confinamiento decretadas a causa del COVID-19.

Cada liturgia se desarrolló durante 20 minutos en las horas de la mañana. El propósito central de la primera sesión consistió en escuchar la lectura de poemas de la voz del poeta invitado Jorge Castellanos, para introducir los niños en el mundo poético. El encuentro se estructuró en tres momentos: 1) presentación del poeta invitado y comentario breve sobre su experiencia estética; 2) lectura en voz alta por parte del poeta, de un poema propio; 3) lectura en voz alta de otros poemas del invitado, por parte de los estudiantes. Finalmente, conversación sobre el sentido y sensaciones que produjeron en los nińos.

\section{Liturgia Literaria 1: Inmersión en la Experiencia de Sensibilización y} Ensońación Poética. El poeta comentó su experiencia estética de este modo:

Mi largo caminar por la poesía comenzó desde antes de nacer, pues, en mi 
familia siempre fueron estupendos oradores y escritores. Al momento de nacer el primer ruido que llegó a mis oídos fue el de las máquinas de impresión, el primer olor que percibí fue el olor del papel y de la tinta y mis juguetes fueron papeles de colores e imprentas. Mi casa era un sitio romántico y precioso, allí nos reuníamos para escuchar historias y leer novelas. Yo creo que leí los tres mosqueteros y las obras de Julio Verne antes de saber leer, porque, en la casa se hablaba mucho de literatura, todas esas cosas niños [...] me metieron de lleno en las letras, o sea, en la escritura, ya que no tenía escapatoria de ser poeta.

La confesión del poeta muestra el papel que cumple la familia en la formación del pensamiento creativo y del hábito lector. Sin duda, los padres son motivadores y los primeros maestros que involucran al niño en el placer literario. Luego, el invitado leyó en voz alta un poema inédito de su autoría.

Segura Derrota

"Quisiera cualquier día

despertarme en cualquier cama

de cualquier pieza

de cualquier hotel

Salir a cualquier parte

tomar una calle cualquiera

comer en cualquier restaurante

llegar a cualquier terminal de buses

comprar un pasaje a cualquier destino

subirme a cualquier bus

consumir cualquier alimento

arribar a una ciudad cualquiera

hospedarme en cualquier parte

dormir en cualquier cama

asearme en cualquier baño

caminar por cualquier parte

para llegar a cualquier lugar

y fracasar en cualquier parte" (Castellano, s.f.).

A continuación, las reflexiones del poeta sobre el poema precitado:

Ver muchos edificios en ruinas y casas caídas, pero no físicos sino humanos y ver tanta gente que camina por las calles fracasadas. Pero ¿Por qué fracasan? Porque como dice el poema van a cualquier parte sin rumbo fijo, es decir, nacen, crecen, se reproducen y mueren como cualquier vegetal. Esto implica que, si vivo por vivir, me dejo llevar por las personas sin proyecto de vida y muy seguramente vendrá un terrible fracaso. Por el 
contrario, cuando la gente sabe para dónde va, allá llegará

A propósito de lo expuesto, Jaramillo (1985) remarca que ningún poeta se conforma con sus cinco sentidos, por ello, ejercita el de la orientación, la observación, el sentido común, el sin sentido, el sentido de la realidad y el de la irrealidad, el de la poesía, el del absurdo, el de percepción extrasensorial, el mágico, el de los sueños, el de la velocidad y el de la quietud. Efectivamente el texto poético presenta la realidad, es una imagen de ella; el texto se convierte en un espejo del hombre, de su ser, y de su relación con el mundo (Avendaño, 2010).

Los estudiantes leyeron en voz alta otros poemas del autor invitado, ¿Qué es un poema? e Imposible y Papel, lo que le causó gran emoción al escuchar sus poemas en las voces de los niños. Después de cada lectura, se aludió a momentos de ensońación que posibilitaron la epifanía de cada verso y comentó que su poesía surge de la experiencia, de sentimientos encontrados y de la materialización de sueños. Un estudiante le preguntó al poeta ¿Qué es un poema? y él respondió: "poema es sentimiento, porque el poeta vive del sentimiento que se viste de palabras".

Como se puede ver, las liturgias literarias fueron espacios para disfrutar la poesía, para conocer de la viva voz del autor esa revelación poética, para sensibilizar a los estudiantes y exhortarlos a la expresión de sus sentimientos que emergen de experiencias familiares, escolares y sociales. Además, para hacer notar la importancia de escuchar al otro.

La interlocución entre autor, poema y lector se convirtió en un espacio emotivo para los estudiantes, pues contribuyó a explorar la propia sensibilidad, a través del contacto con la poesía y la interacción comunicativa directa con poetas vivos. En la sesión, el poeta invitó a imaginar los propios proyectos de vida, repensar las vivencias del presente, desterrar la indiferencia ante lo que ocurre en el mundo, asombrarse y dejarse cautivar por la naturaleza y los pequeños detalles, recordar momentos de la infancia, valorar la familia, los amigos y la escuela, y, contemplar y describir lugares inolvidables.

Experiencias Estéticas e Interpretativas en el Ámbito de las Tertulias Literarias.

Tertulia Literaria 1. Un Viaje al Pasado. Se desarrollaron siete tertulias literarias, pero aquí solo se describe y analiza los resultados de la primera, cuyo objetivo fue crear un ambiente propicio para que los estudiantes se familiarizaran con el ritmo, la música y el maravilloso mundo del poema Los maderos de San Juan de José Asunción Silva. Este encuentro poético duró 60 minutos y tuvo lugar en la plataforma virtual Google Meet. Se estructuró a partir de tres ciclos: 1) acercamiento con actividades de ambientación, lectura en voz alta, musicalización del poema, contextos de autor y análisis de la sonoridad del texto poético; 2) Se dedicó al disfrute del poema, los estudiantes lo leyeron en voz alta y lo entonaron con diferentes ritmos, y se exploraron 
las experiencias interpretativas, abriendo espacio para que los nińos expresaran sus ensueños -imaginaciones, fantasías y recuerdos provocados por el poema-; sentidos ocultos para llenar los agujeros, o vacíos luminosos de los versos; emociones; sensaciones; sentimientos e inferencia del motivo temático. 3) Se convirtió en un espacio para recontextualizar el poema, es decir, para ponerlo en el entorno real del estudiante. Se hace necesario aclarar que aquí se presenta solo una breve muestra de las experiencias interpretativas del poema precitado.

Todos los encuentros poéticos se apoyaron en la formulación de interrogantes encaminados a explorar en los niños sus percepciones, sensaciones, emociones, ensueńos, asociaciones y capacidad de cubrir los agujeros o vacíos luminosos del texto con múltiples sentidos. Así mismo, fueron momentos lúdicos, felices y de liberación de sentimientos, por cuanto lo que da acceso a experiencias de catharsis, es el goce estético que se siente al sumergirse en la obra, decirla en voz alta, experimentar sensaciones de asombro, risa y alegría con total libertad (Jauss, 1986). Al respecto, Paz (2003) concibe la poesía como liberación, conocimiento, poder y abandono. Para iniciar el acercamiento al poema se proyectó un video que contiene un coro relacionado, luego se formularon preguntas y los nińos respondieron a cada una. Véase una muestra de este diálogo poético:

“¿Habían escuchado antes esta canción? sí la he escuchado; ¿Dónde? en la casa; ¿Cuándo? cuando arrullan a los niños, en las rondas de los jardines, cuando era pequeño; ¿Qué les gustó más, la música, el ritmo o la letra del poema? la música, la letra."

Se resalta la pertinencia y la relevancia de la música que acompañó al poema, pues emocionó a los niños, los motivó, les generó alegría y los transportó a su infancia. Esto es, entraron en momentos de ensueńo a través de los recuerdos agradables que les evocó el poema de Silva.

Después, la docente leyó en voz alta los versos extensos del poema, y musicalizó los cortos. Con el apoyo de diapositivas pidió a los estudiantes que siguieran la lectura mentalmente. Luego les preguntó:

“¿Qué vino a sus mentes? ¿Qué les impactó? ¿Cuáles fueron sus sensaciones, impresiones y evocaciones que les trajo el poema? ¿Qué sintieron al escucharlo? [Estas fueron las respuestas de algunos niños] cuando era pequeño y estaba en el jardín; me trajo recuerdos de alegría; recordé mi niñez cuando estaba en el jardín; los momentos que he estado con mis compañeros."

Esas sensaciones corresponden a la vivencia de estados de ensońación proporcionados por la lectura del poema, lo cual coincide con los postulados de Bachelard (2002) referidos a la concepción del ensueño como la amalgama entre imaginación y memoria. La lectura poética incentiva en el lector la capacidad de imaginación, y de emprender viajes hacia el pasado. A partir de la lectura, el 
estudiante es afectado, pues la pedagogía de la imaginación poética permite que recurra a la historia y a sus experiencias de vida, para crear símbolos latentes en su realidad (Goyes, 2012).

Además, se indagó por el aspecto formal del poema con los siguientes interrogantes: “¿Cuántas estrofas tiene el poema? ¿Cómo son los versos: extensos, breves, medianos? ¿Tiene rima? ¿Qué entienden por rima? ¿Cuáles son los versos que riman entre sí?” Algunos estudiantes reconocieron el número de versos y estrofas, pero sobre la rima dudaron, así que fue necesario dar la explicación respectiva. Con lo anterior, se mostró a los participantes que existen poemas clásicos, creados con determinadas técnicas estilísticas para dar musicalidad y sonoridad, especialmente, los que están dirigidos a los niños.

Para abordar la experiencia estética e interpretativa, y el goce, los niños cantaron el poema y se les exhortó a cargar de sentido los agujeros de las distintas imágenes poéticas. Avendaño (2010) plantea que al leer un poema asoman diversas interpretaciones, brota un diálogo externo que consiste en preguntas sucesivas cuyas respuestas interrogan nuevamente. Así que, con ayuda del guion de preguntas los estudiantes dieron sentido al poema con base en sus ensoñaciones, vivencias, sentimientos, emociones y formas de percibir el mundo que los rodea. Se les solicitó leer nuevamente la primera estrofa:

“Aserrin!

¡Aserrán!

Los maderos de San Juan,

piden queso, piden pan,

los de Roque

alfandoque,

los de Rique

alfeñique

¡Los de triqui, triqui, tran!” (Silva, 1996, p.57).

A continuación, se preguntó "En el contexto del poema, ¿qué sentido tienen las palabras maderos, alfandoque, alfeńique y trémulos?" Algunos respondieron: "los maderos son trozos, estructura hecha en madera o, un alfondoque es una golosina elaborada con una mezcla de cańa de azúcar, anís, coco y limón”. Por tanto, se ayudó para que los estudiantes dieran sentido a cada una de las imágenes poéticas, y determinaran lo que estas significan en el poema, no en el diccionario. Los niños leyeron la segunda estrofa del poema y se generó un diálogo a través de preguntas como:

“¿A quiénes se menciona en esa estrofa? a la abuela y al niño. ¿Cómo es la abuela? cariñosa con el niño; cariñosa y con rodillas duras. ¿Cuándo siente alegría ella? cuando el nińo se balancea; cuando comparte con el nieto. ¿Cuándo siente nostalgia? al pensar en el futuro del niño. ¿Cómo es el nieto? pequeño; alegre; 
feliz. ¿Disfrutan el momento? Sí. ¿Qué sentimientos expresa luego la abuela? tal vez aflicción; congoja; zozobra; desconsuelo; decepción ¿Por qué? tristeza porque no va volverlo a ver así de pequeño, no va sentir su cariño y tal vez él no va a saber que ella lo quiso; desconsuelo por el futuro"

Se evidenció que los estudiantes pueden desentrańar los sentidos que están ocultos detrás de las palabras, de las frases y de los versos. A propósito, Avendaño y González (2020) aducen que el sentido de un texto poético no reside solo en las palabras, frases, oraciones, también está en la mente del lector, quien lo construye gracias a "sus presaberes, experiencias de vida, modos de pensar, sentir, sońar y de los contextos socioculturales". (p.158)

“¿La abuela es una mujer con experiencia? sí ¿Por qué? por sus años; porque ella ha sido madre y ha pasado por eso; por las experiencias vividas que ella ha tenido en su vida; son personas sabias en nuestro hogar"

Como se puede ver, las experiencias estéticas e interpretativas desencadenan procesos reflexivos cuando los sentidos ocultos del poema se sacan a la luz y se ponen en el contexto de la realidad del lector, toda vez que lo liberan de su quehacer cotidiano; en el decir de Jauss (1986), este estado de catharsis involucra el proceso comunicativo que le permite al lector reflexionar sobre el texto poético leído.

Las experiencias de lectura expuestas, reflejan que la interpretación de un poema exige que el entendimiento de las ideas literarias se haga propio en uno mismo (Domínguez, 2008). En esta experiencia se evidenció que los niños desplegaron sus propias vivencias y concepciones previas del mundo, para descubrir sentidos implícitos. Ahora, en la siguiente estrofa aparecen estas imágenes poéticas: Esas arrugas hondas, frente mustia ¿Cuál es el sentido de cada una?

Esas arrugas hondas recuerdan una historia

de sufrimientos largos y silenciosa angustia

Y sus cabellos blancos como la nieve están.

De un gran dolor el sello marcó la frente mustia

y son sus ojos turbios espejos que empańaron

los años, y que, a tiempos, las formas reflejaron

De cosas y de seres que nunca volverán (Silva, 1996, p.57).

Las respuestas de los niños señalan que significancia de las palabras expuestas describen a la abuela o, que mustia significa triste. Además, se les pidió que escribieran el sentido de algunos versos. A continuación, se presenta el verso estudiado seguido de las interpretaciones de los nińos. Se aclara que para llenar los agujeros con sentido, fue necesario leer los últimos cuatro versos de la estrofa:

“y son sus ojos turbios espejos que empañaron: que por su tristeza las lágrimas 
empañaron sus ojos.

los ańos, y que, a tiempos, las formas reflejaron: que ya pasó la juventud.

de cosas y de seres que nunca volverán: las personas que nunca volverán es, por ejemplo, el niño que aparece en el poema por el cual la abuela siente angustia; el niño no la volverá a mirar de la misma manera que cuando estaba pequeño".

Solo la segunda respuesta refleja una inferencia, es decir, los estudiantes interpretan las líneas del texto en relación a "que ya pasó la juventud", las demás líneas se quedan aún en la literalidad del texto.

A la pregunta ¿Qué recordará el nieto cuando la abuela ya no esté? los estudiantes respondieron: "el tiempo que pasó con la abuelita; recordará a su abuela y su voz, porque la quería y le da tristeza que ya no la puede ver". Para que los estudiantes complementaran sus interpretaciones, se hicieron otras preguntas como “¿Cómo recordará el nieto a la abuela, con nostalgia, alegría o tristeza? con nostalgia ¿Por qué sufrirá al recordarla? está triste porque no la puede volver abrazar ni dirigirle la palabra”. Estas sensaciones del estudiante corroboran que el acto de la ensońación poética despierta todos los sentidos, inspira, trasmite emociones y revive momentos (Bachelard, 1998).

En las muestras anteriores se observa que algunos niños lograron llenar de sentido los agujeros porque se conectaron con el poema, experimentaron sensaciones disímiles como la alegría y la tristeza, entraron en procesos de ensoñación a través de su imaginación y de sus recuerdos, pues trajeron a sus mentes la imagen de sus propias abuelas y, quizá, evocaron experiencias similares. Entonces, se cubre el agujero cuando el lector poético es capaz de rehacer lo ya hecho, al penetrar en la obra, al recordar vivencias e imaginar para darle sentido y lograr una aproximación al texto. La imaginación es otra forma de tapar esos agujeros, ella permite crear nuevos sentidos y, así, ver lo que se traslapa en la obra (Avendaño, 2010).

Además, los niños en su proceso interpretativo liberaron tensiones cotidianas, disfrutaron, musicalizaron y cantaron, y expresaron sus emociones, sentimientos y conocimientos previos, esa es la catharsis que Jauss (1986) entiende "como el placer que en las propias emociones produce, entre otras creaciones, la poesía, y que puede hacer cambiar de criterio y liberar el ánimo del lector" (p.159). El goce estético genera experiencias de catharsis, dado que el lector se interna en el poema, hace aportes poéticos propios, experimenta ensońaciones y sensaciones de asombro, alegría y nostalgia, y encuentra nuevos saberes, ríe, canta y llora.

En síntesis, a través de las tertulias los niños obtuvieron un contacto más profundo y placentero con la poesía, bucearon en los poemas, los cantaron y desentrańaron diversos contenidos encubiertos tras las palabras, las expresiones, los versos y las estrofas, esto es, ocultos en estos agujeros o vacíos luminosos, que expelen una enorme pluralidad de sentidos. 


\section{Conclusiones}

Los hallazgos de la fase exploratoria mostraron que los niños sí tenían contacto previo con la poesía basado en la memorización y el análisis estilístico. El conocimiento de esta realidad impulsó a pensar la forma de estimular los actos de interpretación, la construcción, desarrollo de liturgias y tertulias literarias, para que generar cercanía, usando poemas con temáticas elegidos por los niños. Las liturgias literarias se convirtieron en momentos lúdicos y de goce estético donde los nińos conocieron poetas vivos, escucharon su voz, dialogaron con ellos, leyeron en voz alta algunas de sus creaciones, se sensibilizaron, expresaron su emotividad y se adentraron en espacios poéticos. Fue emocionante enfrentar a los estudiantes a mundos visibles, en este caso, interactuar con poetas colombianos. Con estas experiencias, la palabra cobra vida, porque conocer de cerca las vivencias estéticas de cada invitado y disfrutar sus libros en físico, hace que los niños se acerquen más a la poesía, la lean con mayor deseo y se atrevan, también, a crear.

Las tertulias literarias fueron momentos en los que se incursionó en experiencias estéticas e interpretativas con profundidad y rigor. Los niños se enfrentaron a poemas de diversos autores y mediante la inmersión en ellos, jugaron a colmar de sentido sus agujeros, además, vivenciaron momentos de ensońación usando su imaginación y sus añoranzas, manifestaron sensaciones de asombro, y expresaron sentimientos como el amor filial y varias emociones más.

En el análisis de las experiencias, se evidencia que los niños dinamizaron la capacidad interpretativa, lo que permitió que vivenciaran el valor de la poesía, gracias a esto, se creó conciencia crítica en ellos como lectores. Al respecto "Schleiermacher asegura que la interpretación es arte creador de la hermenéutica, entendida como crítica y búsqueda de sentido" (Avendaño, 2010, p. 500). La acción interpretativa posibilitó que la imaginación, la sensibilidad y las experiencias de conocimiento, sirvieron como base para que los estudiantes se encontraran consigo mismos y con el otro y analizaran situaciones del diario vivir para reafirmar saberes, convicciones, cambiar de actitud, tomar posiciones y aportar en favor de la transformación en la sociedad. De otra parte, la interpretación poética posibilitó entrar en estados de catharsis, toda vez que los participantes liberaron los miedos, inseguridades, presiones académicas cotidianas, disfrutaron los poemas, los musicalizaron y cantaron.

Es importante señalar que, el maestro debe virar su mirada hacia la pedagogía de la imaginación poética e incluir la poesía en su quehacer docente con deseo y voluntad propia, para orientar procesos de disfrute e interpretación poética en sus estudiantes. Sin duda, la inmersión consuetudinaria del estudiante en experiencias estéticas e interpretativas, a través de espacios lúdicos como las liturgias y las tertulias literarias, impacta favorablemente la capacidad lectora, dado que así, el niño adquiere habilidades para abordar cualquier tipo de texto. 


\section{Referencias}

Avendaño, G., \& González, O. (2020). Una propuesta de plan de clase para dinamizar la lectura crítica. Folios, (52), 155-171. https://doi.org/10.17227/folios.52-10002

Avendaño, G. (2018). Ensueño de imaginación poética en la obra de Julio Flórez. Estudio previo, selección y edición. Universidad Pedagógica y Tecnológica de Colombia

Avendaño, G. (2010). Reseña de: Domínguez Rey, Antonio. Palabra Respirada: hermenéutica de lectura. EPOS, (26), 496-504. http://revistas.uned.es/index. php/EPOS/article/view/10659/10197

Avendaño, G. (2006). Reflexiones en torno de la poesía y del poema. La palabra, (14), 76-86.

Avendaño, G. (2005). Cualificación de los procesos de interpretación, argumentación y proposición. Algunos avances y logros alcanzados. Nuevos Horizontes Pedagógicos, 4, 123-170.

Bachelard, G. (1998). La poética de la Ensoñación. Fondo de Cultura Económica.

Bachelard, G. (2002). La poética del espacio. Fondo de Cultura Económica.

Castellanos, J. (s.f.). Poema Segura derrota. Fuente.

Domínguez, R. (2008). Palabra respirada: Hermenéutica de lectura. UNED.

Gadamer, H. (1977). Verdad y Método. Ediciones Sígueme

Goyes, J. (2012). La imaginación poética: Afectos y Efectos en la Oralidad, la Lectura y la Escritura. Caza de Libros.

Jaramillo, J. (1985). Método fácil y rápido para ser poeta. Luna libros.

Jauss, H. (1986). Experiencia estética y Hermenéutica literaria. Taurus.

Palomo, J. (2013). Didáctica de la lectura literaria. Rutas de lectura y escritura creativa. Editorial Zenú.

Paz, O. (2003). El arco y la lira. Fondo de Cultura Económica

Perriconi, G., \& Wischñevsky, A. (1984) La poesía infantil. Estudio preliminar y antología. El Ateneo Editorial.

Pievi, N., \& Bravin, C. (2009). Documento metodológico orientador para la investigación educativa (1a ed.) Ministerio de Educación de la Nación.

Pound, E. (2000). El ABC de la lectura. Ediciones y Talleres de Escritura Creativa Fuentetaja.

Silva, J. (1996). Obra completa. Ediciones de Centenario; Allca xx; Casa de poesía Silva. 
Ricoeur, P. (1999). El conflicto de las interpretaciones. Fondo de Cultura Económica. Vásquez, F. (2002). La enseña literaria: crítica y didáctica de la literatura. Kimpres. 